\title{
ANALISIS FAKTOR-FAKTOR YANG MEMPENGARUHI PERTUMBUHAN EKONOMI ASEAN MEMBER COUNTRIES PADA TAHUN 2011-2016
}

\author{
Agatha Christy Permata Sari \\ Alumni Fakultas Ekonomi dan Bisnis Pascasarjana Universitas Brawijaya Malang \\ David Kaluge \\ Dosen Pascasarjana Universitas Brawijaya Malang.
}

\begin{abstract}
Economic Growth becomes the important factor to measure how success economic state. Therefore, many country will always try to increase their economic growth for the priority target that must be reached.this research has purpose to present which factor that can influence economic growth in ASEAN member countreias.t There is 10 countries being the sampe country, which is Indonesia, Thailand, Malaysia, Singapore, Philippines,Brunei Darussalam, Vietnam, Laos, Myanmar,and Cambodia. This research use Panel Data Regression, Generalized Least Square (GLS) method and fixed-effect estimation model by using analytical tools help in processing the data which uses Eviews 9 programm. Data is panel data of all ASEAN member countries in 6 year period (2011-2016). Varible that used are : GDP, Import, Export, Foreign Direct Inverstment, Competitiveness Index, Government Expenditure, and Labor force. The result is each independent variable can explain 99,4126\% of dependen variable. Which is, IM (import) variable is the only one variable that has positive significant influence to economic growth. The finding from this research is economic growth phenomenon that occurred in ASEAN is greatly influenced by consumption rather than investment and production. So, almost the entirety of economic growth can be measured by consumption side.
\end{abstract}

Keywords:Economic Growth, Export, Import, Foreign Direct Investment, Government Expenditure,Labor Force, Inflation Rate.

\section{PENDAHULUAN}

Pertumbuhan ekonomi merupakan salah satu indikator penting yang wajib diperhatikan oleh tiap-tiap negara secara global. Dimana pertumbuhan ekonomi menjadi semakin penting untuk dikaji, mengingat setiap negara akan selalu berusaha untuk meningkatkan target ekonomi tersebut sebagai takaran kesuksesan suatu negara dalam kurun waktu panjang. Tidak hanya itu, negara yang mampu mempertahankan bahkan selalu meningkatkan pertumbuhan ekonomi merupakan salah satu prestasi yang tentunya membutuhkan perencanaan dan kewaspadaan dalam pelaksanaan aktifitas ekonomi. Akan tetapi, tidak semua negara mampu mencapai pertumbuhan ekonomi seperti yang dicitacitakan. Keadaan ini terjadi dikarenakan beberapa faktor yang salah satunya adalah ketidakmampuan suatu negara untuk memenuhi kebutuhannya hanya secara domestik. Hal inilah yang kemudian dijadikan sebagai landasan pentingnya kerjasama ekonomi internasional untuk saling mendukung pemenuhan kebutuhan dan terlebih meningkatkan pertumbuhan ekonomi dari pihak yang bersangkutan.

Tidak hanya dari sisi global, secara regional ternyata juga dirasakan oleh beberapa negara bahwa kedekatan secara letak geografis dan juga latar belakang historis yang hampir sama kemudian mendorong beberapa negara membentuk organisasi regional. Organisasi ini berisikan negaranegara di suatu kawasan dengan fokus yang sama yakni salah satunya adalah mencapai pertumbuhan ekonomi yang meningkat. Salah satunya adalah ASEAN (Association South East Asia Nation) yang merupakan organisasi atau himpunan dari sepuluh negara yang secara geografis terletak di kawasan Asia Tenggara. ASEAN telah dibentuk sejak 8 Agustus 1967 di Bangkok. Organisasi Internasional ini dibentuk guna mencapai tujuan dari kepentingan negara-negara anggota baik dari sisi ekonomi, sosial, budaya, dll. Terbentuknya ASEAN selama kurang lebih 5 dekade ini mengakibatkan memudarnya batas-batas aktivitas perekonomian. Dimana ini merupakan salah satu pengaruh dari tuntutan era globalisasi bahwa setiap negara diharapkan mampu untuk melakukan perdagangan dan perekonomian terbuka. Dengan adanya kerjasama ekonomi regional ini ditujukan untuk meningkatkan pertumbuhan ekonomi ASEAN baik sejak terbentuk, hingga jangka waktu selanjutnya.

Faktanya, pertumbuhan ekonomi yang terjadi di negara-negara ASEAN masih saja tidak stabil. Keadaan ini tentu saja berseberangan dengan tujuan awal 
pembentukan ASEAN yang ingin meningkatkan pertumbuhan ekonomi dari masing-masing negara anggota. Terlebih pada kurun waktu 2011-2016, pertumbuhan ekonomi negara-negara anggota ASEAN bersifat sangat fluktiuatif. Kondisi ini dapat dilihat melalui grafik di bawah ini:

Gambar 1. Rata-Rata Pertumbuhan Ekonomi Negara-Negara ASEAN (2011-2016).

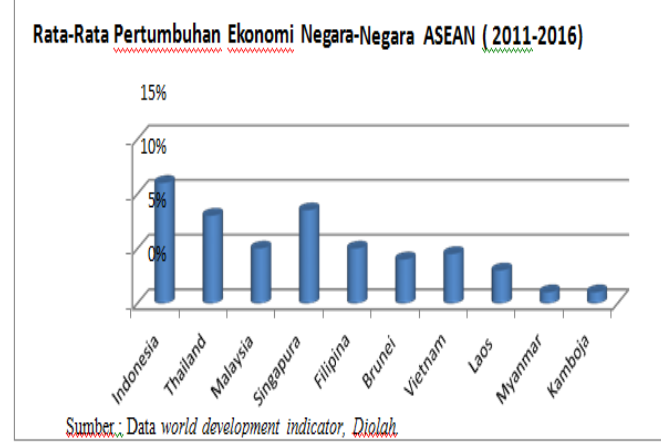

Sumber : Data world development indicator, Diolah.

Dari grafik diatas, terlihat bahwa ratarata pertumbuhan ekonomi dari masingmasing negara bervariasi, dimana Indonesia sejumlah $11 \%$, dilanjutkan dengan singapura sebesar $9 \%$, thailand $8 \%$, dilanjutkan dengan Malaysia, Filipina, dan Vietnam sebesar 5\%, Brunei sebesar $4 \%$ dan dua dari terakhir, Myanmar dan Kamboja sejumlah $1 \%$. Dengan kenyataan bahwa pertumbuhan ekonomi yang dialami oleh negara ASEAN berbeda-beda, maka memunculkan pertanyaan faktor-faktor apa saja yang mempengaruhi pertumbuhan ekonomi di kawasan Asia Tenggara. Perbedaan pertumbuhan ekonomi yang dirasakan oleh masing-masing negara ini kemudian menimbulkan keraguan dari beberapa negara dalam menghadapi pembentukan ASEAN Economic Commmunity (AEC) atau yang lebihdikenal dengan Masyarakat Ekonomi ASEAN. Untuk itu, perlu diteliti apa saja faktor yang mempengaruhi pertumbuhan ekonomi di negara ASEAN.

Dalam salah satu penelitian terdahulu, dijelaskan bahwa terdapat beberapa faktor yang sangat mempengaruhi pertumbuhan ekonomi. Faktor-faktor tersebut meliputi: inflasi, konsumsi pemerintah, aturan hukum, ketentuan perdagangan, maupun tingkat kelahiran yang terjadi dalam suatu negara (Barro,1997). Dari studi empiris tersebut, dalam penelitian ini, maka dipilih beberapa variabel-variabel yang mempengaruhi pertumbuhan ekonomi ( dengan proxy GDP) baik dari sisi konsumsi, investasi maupun produksi, antara lain terpilih variabel sebagai berikut : Impor, Eskpor, Foreign Direct Investment, Competitiveness Index, Government expenditure, dan labor force. Dengan dibentuknya penelitian ini diharapkan dapat menjawab rumusan masalah dan menemukan temuan baru dari hasil regresi data panel dalam data-data sekunder yang telah dikumpulkan melalui sumber resmi. Dan tentunya kemudian diuji dengan menggunakan model persamaan ekonometrika yang tepat dan telah diuji. Sehingga mendapatkan hasil dan kesimpulan yang baik.

\section{RUMUSAN MASALAH}

Dari pemaparan latar belakang di atas, dijelaskan bahwa pertumbuhan ekonomi di kawasan ASEAN fluktuatif. Dari sanalah kemudian akan dianalisis dengan pendekatan faktor-faktor yang berpengaruh pada pertumbuhan ekonomi. Kemudian dibentuk rumusan masalah sebagai berikut:

1. Apakah variabel-variabel independen yang meliputi: Impor, Eskpor, Foreign Direct Investment, Competitiveness Index, Government expenditure, dan labor force mampu menjelaskan variabel independen yakni pertumbuhan ekonomi (GDP) ?

2. Variabel manakah yang memiliki kontribusi / pengaruh terbesar pada pertumbuhan ekonomi di ASEAN?

\section{TUJUAN PENELITIAN}

Tujuan dari penelitian ini adalah untuk mengetahui seberapa besar pengaruh dari Impor, Eskpor, Foreign Direct Investment (FDI), Competitiveness Index, Government Expenditure, dan Labor Force dalam pertumbuhan ekonomi di negara-negara ASEAN. Dan kemudian akan menghasilkan variabel apa yang memberikan kontribusi terbesar pada pertumbuhan ekonomi.

\section{METODE PENELITIAN}

Penelitian ini menggunakan pendekatan eksplanatif yang menjelaskan hubungan antar variabel melalui pengujian hipotesis. Dimana data yang digunakan merupakan gabungan dari data time series dan cross-section yang dikenal dengan data panel. Data panel merupakan data dari satu atau beberapa 
variabel yang dikumpulkan secara berkala dalam kurun waktu tertentu (Gujarati,2003). Pada data panel, unit crosssection yang sama disurvei selama beberapa waktu. Oleh karena data panel merupakan gabungan dari data time-series dan crosssection, maka data panel memberikan data yang lebih banyak dan informative (Baltagi,2005).

Dalam mengaplikasikan data panel, dapat menggunakan metode regresi data panel. Secara umum model regresi data panel dapat dilakukan dalam dua pendekatan, yakni pendekatan fixed effect dan pendekatan random effect. Sehingga dalam melakukan regresi harus memilih salah satu pendekatan yang menghasilkan model yang signifikan. Sehingga model regresi yang baik harus didasarkan pada pengujian hipotesis.

Model regresi data panel, dikenal juga sebagai analisis regresi linear berganda, dimana metode statistic yang digunakan adalah untuk menganalisis hubungan antara variabel dependen dan variabel independen (Supranto,2001). Secara umum, persamaan regresi data panel adalah sebagai berikut ini (Drapper and Smith, 1992):

$Y t=\alpha+\beta_{1} X_{1} t+\beta_{2} X_{2} t+\beta_{3} X_{3} t \ldots+e t$

Keterangan:

$\mathrm{Y}=$ Variabel Dependen

$\beta=$ Koefisien Variabel Independen

$X=$ variabel independent

$\mathrm{t}=$ waktu ke $\mathrm{t}$

$\mathrm{e}=$ variabel error

Penelitian ini menggunakan periode waktu 6 tahun, yakni dari tahun 2011-2016 dengan 10 negara anggota ASEAN. Data yang digunakan berupa data sekunder yang diperoleh dari trading economic, world development indicator,world bank dan sejumlah literature official lain. Sesuai dengan penjelasan sebelumnya, alat analisis yang digunakan adalah regresi data panel. Langkah pertama adalah melakukan Uji Chow untuk menentukan model yang digunakan termasuk dalam common effect atau fixed effect. Langkah kedua, dilakukan Uji Hausman untuk menentukan model yang dipilih masuk ke dalam fixed effect atau random effect. Kedua langkah tersebut diilakukan untuk menentukan model terbaik yang akan digunakan dalam penelitian ini. Beberapa variabel yang digunakan dalam penelitian ini adalah antara lain:

1. (Y) Pertumbuhan ekonomi dengan proxy Gross Domestic Product (GDP), yakni pendapatan masing-masing negara anggota ASEAN selama kurun waktu 2011-2016, sebagai variabel dependen.

2. (X1) - Impor (IM) yang dilakukan oleh masing-masing negara ASEAN selama kurun waktu 2011-2016, sebagai variabel independen.

3. (X2) - Ekspor (EX) yang dilakukan oleh masing-masing negara ASEAN selama kurun waktu 2011-2016, sebagai variabel independen.

4. (X3) - Foreign Direct Investment (FDI), merupakan investasi yang diperoleh negara-negara ASEAN dalam kurun waktu 2011-2016, sebagai variabel independen.

5. (X4) - Competitiveness Index (CI) merupakan indeks daya saing bisnis secara domestic yang dimiliki oleh negara-negara ASEAN dalam kurun waktu 2011-2016, sebagai variabel independen

6. (X5) - Government Expenditure (GOV) merupakan pengeluaran pemerintah diukur melalui APBN masing-masing negara dalam kurun waktu 2011-2016, sebagai variabel independen

7. (X6) - Labor Force (LAB) merupakan jumlah angkatan kerja yang bekerja mampu dan secara produktif mendapatkan penghasilan di masingmasing negara ASEAN pada kurun waktu 2011-2016, sebagai variabel independen

Dalam penelitian ini, menganalisis enam faktor yang mempengaruhi pertumbuhan ekonomi di ASEAN, menggunakan alat analisis metode analisis linear berganda dengan menggunakan data panel, sehingga membentuk persamaan model sebagai berikut ini:

$$
\begin{aligned}
& G D P_{t}=a+\beta_{1} I M_{t}+\beta_{2} E X_{t}+\beta_{3} F D I_{t}+\beta_{3} C I_{t}+\beta_{4} G O V_{t}+ \\
& \beta_{5} L A B_{t}+\ldots . . e t
\end{aligned}
$$

Dengan menggunakan persamaan model seperti diatas ini dan melakukan analisis menggunakan regresi data panel dengan dua uji kelayakan terhadap model tersebut, maka diharapkan akan memperoleh hasil yang mampu menjawab rumusan masalah dan tujuan yang dibentuk dalam penelitian ini.

\section{HASIL UJI DAN PEMBAHASAN}

Seperti yang dijelaskan sebelumnya, dalam penelitian ini menggunakan dua uji 
dari data yang telah dikumpulkan. Dari hasil uji chow menunjukkan bahwa tingkat probabilitas $P$-Value atau yang probabilitas c-square dan uji f adalah 0.0000. Dari sini dapat disimpulkan bahwa pada $\alpha 5 \%$ atau 0.05 , maka niai $\mathrm{p}<\alpha$ atau $0.0000<0.5$. Dengan begitu, hasil uji menandakan bahwa $\mathrm{H}_{0}$ ditolak, dan $\mathrm{H}_{1}$ diterima. Sehingga, model yang dipilih adalah fixed effect. Hasil penelitian melalui fixed effect, adalah sebagai berikut ini:

\begin{tabular}{|c|c|c|c|}
\hline \multicolumn{4}{|c|}{$\begin{array}{l}\text { Redundant Fixed Effects Tests } \\
\text { Equation: Untitled } \\
\text { Test cross-section fixed effects }\end{array}$} \\
\hline Effects Test & mstatisticon & unnidf. & Rrob. \\
\hline Cross-section F & 123.893301 & $(9.44)$ & 0.0000 \\
\hline Cross-section Chi-square & 196.269448 & 9 & 0.0000 \\
\hline
\end{tabular}

Sumber: Hasil Output Regress data panel dengan regresi exiews 9.0

$$
\begin{aligned}
& \mathrm{H}_{0}=\text { Model mengikuti pooled least square } \\
& \mathrm{H}_{1}=\text { Model mengikuti fixed effect }
\end{aligned}
$$

Selanjutnya, dilakukan uji Hausman $p$-value atau hasil probabilitas sebesar 0.0164 Dengan tingkat kesalahan $\alpha 5 \%$ atau $0.05 \%$ maka $p$-value $<\alpha$ atau $0.0164<0.05$. Sehingga yang cocok dipilih dalam penelitian ini adalah fixed effect model. Hasil uji Hausman dapat diperhatikan melalui tabel 2, sebagai berikut ini:

Tabel 2. Hasil Uji Hausman

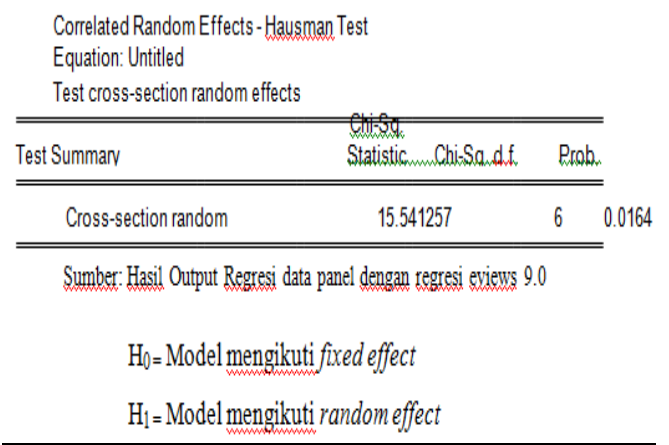

Berdasarkan hasil dari uji Chow dan Uji Hausman, maka dapat ditentukan bahwa model yang akan digunakan dalam penelitian ini adalah menggunakan fixed effect model. Selanjutnya, data yang telah dikumpulkan akan dianalisis menggunakan regresi seperti tabel 3 di bawah ini:

Tabel 3. Hasil Regresi denga Metode Fixed

\begin{tabular}{|c|c|c|c|c|}
\hline \multicolumn{5}{|c|}{$\begin{array}{l}\text { Dependent Variable: GDP } \\
\text { Method: Panel Least Squares } \\
\text { Date: 01/12/17 Time: } 11: 21 \\
\text { Sample: } 20112016 \\
\text { Periods included: } 6 \\
\text { Cross-sections included: } 10 \\
\text { Total panel (balanced) observations: } 60\end{array}$} \\
\hline Variable & Coefficient & Std. Error & t-Statistic & Prob. \\
\hline $\begin{array}{l}\text { C } \\
\text { IM } \\
\text { EX } \\
\text { FDI } \\
\text { Cl } \\
\text { GOV } \\
\text { LAB }\end{array}$ & $\begin{array}{r}63.29157 \\
17.04623 \\
-1.758769 \\
1.733793 \\
29.76859 \\
-0.906927 \\
-0.111629\end{array}$ & $\begin{array}{l}101.5406 \\
3.110794 \\
1.611552 \\
0.884476 \\
18.81243 \\
1.151111 \\
0.571196\end{array}$ & $\begin{array}{r}0.623313 \\
5.479703 \\
-1.091351 \\
1.960250 \\
1.582389 \\
-0.787871 \\
-0.195431\end{array}$ & $\begin{array}{l}0.5363 \\
0.0000 \\
0.2811 \\
0.0563 \\
0.1207 \\
0.4350 \\
0.8460\end{array}$ \\
\hline \multicolumn{5}{|c|}{ Effects Specification } \\
\hline \multicolumn{5}{|c|}{ Cross-section fixed (dummv variables) } \\
\hline $\begin{array}{l}\text { R-squared } \\
\text { Adjusted R-squared } \\
\text { S.E. of regression } \\
\text { Sum squared resid } \\
\text { Log likelihood } \\
\text { F-statistic } \\
\text { Prob(F-statistic) }\end{array}$ & $\begin{array}{r}0.994126 \\
0.992124 \\
22.46051 \\
22196.89 \\
-262.5372 \\
496.4491 \\
0.000000\end{array}$ & \multicolumn{2}{|c|}{$\begin{array}{l}\text { Mean dependent var } \\
\text { S.D. dependent var } \\
\text { Akaike info criterion } \\
\text { Schwarz criterion } \\
\text { Hannan-Quinn criter. } \\
\text { Durbin-Watson stat }\end{array}$} & $\begin{array}{l}235.3353 \\
253.0789 \\
9.284573 \\
9.843065 \\
9.503030 \\
1.537793\end{array}$ \\
\hline
\end{tabular}
Effect

Sumber: Hasil Output Regresi data panel dengan regresi eviews 9.0

Berdasarkan dari hasil uji regresi menggunakan fixed effect model yang disajikan dalam Tabel 3, maka dapat dilihat IM (impor) memiliki nilai konstanta sebesar 17.04623 dengan probabilitas sebesar 0.0000 , dimana nilai $0.0000<0.05$. Dengan begitu, IM berpengaruh signifikan positif pada pertumbuhan ekonomi, yang berarti IMP berpengaruh pada pertumbuhan ekonomi. Sedangkan 5 variabel lain yang digunakan dalam penelitian ini tidak memiliki pengaruh pada pertumbuhan ekonomi.

Diawali dengan EX (ekspor) memiliki nilai konstanta sebesar -1.758769 dengan probabilitas 0.2811 , dimana $0.2811>$ 0.05. Sehingga EX memiliki nilai negative dan tidak signifikan. FDI (foreign direct investment) memiliki nilai konstanta sebesar 1.733793 dengan probabilitas 0.0563 , dimana $0.0563>0.05$.

Sehingga FDI memiliki nilai positif dan tidak signifikan. CI (Competitiveness Index) memiliki nilai konstanta sebesar 29.76859 dengan probabilitas 0.1207 , dimana 0.1207 > 0.05. Sehingga FDI memiliki nilai positif dan tidak signifikan. 
Selanjutnya, adalah GOV (government expenditure) memiliki nilai konstanta sebesar -0.906927 dengan probabilitas 0.4350 , dimana $0.4350>0.05$. Sehingga FDI memiliki nilai negative dan tidak signifikan. Dan yang terakhir adalah LAB (labor force) memiliki nilai konstanta sebesar -0.111629 dengan probabilitas 0.8460 , dimana $0.8460>0.05$. Sehingga LAB memiliki nilai negative dan tidak signifikan. Dengan begitu, variabel EX, FDI, CI, GOV, dan LAB tidak memiliki pengaruh pada pertumbuhan ekonomi (GDP). Melalui Tabel 3, dapat diketahui bahwa uji f statistic sebesar 0.0000. Dimana $0.0000<0.5$, maka variabel independen secara bersama-sama dapat menjelaskan variabel dependen. Sementara itu, pada uji koefisien determinasi $\mathrm{R}^{2}$, didapatkan nilai sebesar 0.994126. Dimana dapat dijelaskan bahwa variabel 99,4126\% variasi pertumbuhan ekonomi (dengan proxy GDP) dapat dijelaskan oleh variabel independent dalam model, yakni: impor,ekspor, foreign direct investment, competitiveness index, government expenditure, dan labor force. Sedangkan $0.5874 \%$ dapat dijelaskan oleh variabel lain.

Dari hasil regresi yang ditampilkan menunjukkan bahwa variabel independen yang meliputi impor, ekspor, foreign direct investment, competitiveness index, government expenditure, dan labor force secara simultan berpengaruh pada variabel dependen pertumbuhan ekonomi (GDP). Hal ini dapat dibuktikan melalui nilai $\mathrm{f}$ statistik yang $<0.05$. Nilai $\mathrm{R}^{2}$ yang didapat dari hasil regresi sebesar 0.994126 yang menunjukkan bahwa variabel independent mampu menjelaskan $99 \%$ variabel dependen, dan sisanya dijelaskan oleh variabel lain.

\section{KESIMPULAN}

Hasil penelitian menunjukkan bahwa variabel independent yang meliputi : impor, ekspor, foreign direct investment, competitiveness index, government expenditure, dan labor force secara simultan berpengaruh pada variabel dependen pertumbuhan ekonomi (GDP). Dan memiliki Nilai $\mathrm{R}^{2}$ yang didapat dari hasil regresi sebesar $0.994126 \quad$ yang menunjukkan bahwa variabel independent mampu menjelaskan $99.412 \%$ variabel dependen yang dalam penelitian ini pertumbuhan ekonomi. Dan $0.5874 \%$ dijelaskan oleh variabel lain.
Dimana dari lima variabel independen yang dipilih, hanya satu variabel yang memiliki pengaruh pada pertumbuhan ekonomi (GDP), yakni Impor (IM). Sehingga dibandingkan variabel yang lain, variabel inilah yang memiliki pengaruh paling besar terhadap pertumbuhan ekonomi (diproxykan dengan GDP). IM memiliki nilai konstanta sebesar 17.04623 dengan probabilitas sebesar 0.0000 , dimana nilai $0.0000<0.05$. Dengan begitu, IM berpengaruh signifikan positif pada pertumbuhan ekonomi, yang berarti IM berpengaruh pada pertumbuhan ekonomi. Sehingga, ketika IM meningkat $1 \%$, maka pertumbuhan ekonomi di negara-negara ASEAN akan meningkat 17\%. Sedangkan, untuk variabel lainnya, yakni ekspor, government expenditure, labor force memiliki nilai negative dan tidak signifikan. Serta foreign direct investment, competitiveness index memiliki nilai positif dan tidak signifikan.

Melalui penelitian ini didapatkan temuan bahwa pertumbuhan ekonomi yang dialami oleh negara-negara anggota ASEAN sangat dipengaruhi oleh impor. Dimana pertumbuhan akan meningkat sebesar $17 \%$, ketika variable impor meningkat sebesar $1 \%$. Hal ini menandakan bahwa pertumbuhan ekonomi di ASEAN sangat dipengaruhi oleh tingkat konsumsi melebihi investasi dan produksi. Budaya konsumerisme yang tinggi oleh masyarakat di Asia Tenggara inilah yang kemudian menjadi indikator dan bukti bahwa negara tersebut mengalami pertumbuhan ekonomi terjadi di negara yang bersangkutan. Mengapa hal tersebut terjadi? Ini dapat dijawab dengan analogi bahwa, ketika masyarakat memiliki daya beli yang cukup tinggi akan barang-barang impor dengan jumlah yang banyak, maka dapat dipastikan bahwa masyarakat di suatu negara tersebut memiliki kemampuan untuk membeli yang ditopang oleh pendapatan yang dimiliki. Sehingga ketika impor disuatu negara naik, maka pertumbuhan ekonomi yang diukur melalui GDP dapat dipastikan naik (memiliki pengaruh signifikan positif). Dalam penelitian ini juga ditemukan bahwa Indonesia merupakan salah satu negara anggota ASEAN yang memiliki pertumbuhan

ekonomi paling tinggi dibandingkan negara anggota lain. Sehingga dapat disimpulkan, Indonesia memiliki tingkat budaya konsumerisme akan barang impor yang cukup tinggi dengan pertumbuhan ekonomi paling tinggi dibandingkan negara anggota ASEAN lainnya. 


\section{Daftar Pustaka}

1. Barro, Robert J.1997. Determinant of Economics Growth: A Cross Country Empirical Study, London: The MIT Press Cambridge, Massachussetts.

2. Drapper, N, dan Smith, H. 1992. Analisis Regresi Terapan. Jakarta : Gramedia Pustaka Utama.

3. Ekananda, Mahyus. 2014. Analisis Ekonometrika Data Panel.Jakarta: Mitra Wacana Media.

4. Kementerian Perdagangan Republik Indonesia, 2011. Мепији ASEAN Economic Community 2015, Jakarta.

5. Kementerian Perdagangan Republik Indonesia.2011. Chartbook 2010 Masyarakat Ekonomi ASEAN, Jakarta.
6. Mankiw, N. Gregory, 2006. Principle of Macroeconomic, International Student Edition, Third Edition, Singapore : Thomson South-Western.

7. Green, William H. 2003. Econometric Analysis, Fifth Edition, USA: New York University,Prentice Hall Inc.

8. Gujarati, Damodar,1995, Ekonometrika Dasar, Alih Bahasa Sumarno Zain, Erlangga,Jakarta.

9. Gujarati, Damodar,1993. Basic Econometrics $4^{\text {th }}$ Edition. New York: McGraw-Hill Inc.

10. Supranto, J. 2001. Statistik Teori dan Aplikasi. Jakarta: Erlangga 